\title{
PENGARUH MOTIVASI DAN KEMAMPUAN MANAGERIAL TERHADAP KINERJA USAHA KECIL DAN MENENGAH DI KOTA MEDAN
}

\author{
Oleh: \\ Rasmulia Sembiring \\ Univesitas Methodist Indonesia Medan
}

\begin{abstract}
Abstraksi
Penelitian ini bertujuan untuk menguji pengaruh persepsi dan loyalitas orangtua murid terhadap keputusan pemilihan jasa pendidikan di TK Swasta Sultan Agung Pematangsiantar, dengan citra TK Swasta Sultan Agung Pematangsiantar sebagai variabel mediasi. Jumlah sampel adalah 170 orang dengan teknik pengambilan sampel menggunakan teknik non-probability sampling dengan metode accidental sampling yaitu pengambilan sampel secara kebetulan bagi orang tua murid TK Swasta Sultan Agung Pematangsiantar yang pada saat itu berada di lokasi TK Swasta Sultan Agung Pematangsiantar. Instrumen penelitian ini adalah kuesioner yang dibagikan kepada responden untuk mencari data yang berhubungan dengan penelitian ini. Metode analisis data yang digunakan adalah Analisis Kuantitatif dan Analisis Kualitatif. Analisis Kuantitatif menggunakan metode Analisis SEM dengan aplikasi Amos 22.0, untuk mengukur pengaruh dari variabel bebas terhadap variabel terikat yaitu persepsi dan loyalitas terhadap keputusan dengan citra sebagai mediasi. Hasil penelitian dan uji hipotesis menunjukkan bahwa variabel persepsi dan loyalitas berpengaruh signifikan terhadap keputusan baik secara parsial maupun simultan. Variabel persepsi dan loyalitas berpengaruh signifikan terhadap citra baik secara parsial maupun simultan. Variabel citra berpengaruh signifikan terhadap keputusan, dan variabel citra memediasi hubungan persepsi dan loyalitas terhadap keputusan pemilihan jasa pendidikan di TK Swasta Sultan Agung Pematangsiantar.

Temuan empiris tersebut mengindikasikan bahwa untuk meningkatkan jumlah murid, maka TK Swasta Sultan Agung Pematangsiantar perlu memperhatikan faktor-faktor yang mempengaruhi keputusan konsumen dalam memilih jasa pendidikan, seperti persepsi, loyalitas dan citra. Karena dengan mengetahui pengaruh hubungan tersebut dapat dijadikan acuan untuk merancang strategi guna meningkatkan jumlah murid setiap tahunnya.
\end{abstract}

Kata kunci : Persepsi, Loyalitas, Citra dan Keputusan Pemilihan Jasa Pendidikan

\section{Abstraction}

The objective of this research is to test the influence of perception and loyality of students parents against the decision of the selection of educational service in TK Sultan Agung Pematangsiantar with the image of TK Sultan Agung Pematangsiantar as the mediating variable. The number of samples are 170 people by using non-probability sampling technique and accidental sampling technique taken coincidentally from students parents in the area of TK Sultan Agung Pematangsiantar. The instrument of this research is questionnaires were distributed to the respondens to find data related to this research. It is analyzed in quantitative and qualitativelty research. Quantitative research uses SEM analysis method with AMOS 22.0 application, to measure the influence of independent variables toward dependent variables, that is perception, loyalty against decision with image as the mediation. The research result and hypothesis indicate that perception and loyalty variables influence significantly toward the decision partially and simultaneously. Image variable influence significantly toward the decision and image variabel mediates the relation between perception and loyalty toward the decision of selection of education service in TK Sultan Agung Pematangsiantar.

The empirical finding indicates that the management of TK Sultan Agung Pematangsiantar need to observe the factors influence customers' decision in choosing educational services, like perseption, loyalty and image. By knowing the effects of the relation, it can be references to design a plan stratey in order to increase the number of students every year.

Keywords : Perception, Loyalty, Image and Decision To Select Educational Service

\section{A. PENDAHULUAN}

1. Latar Belakang Masalah

Salah satu pelaku usaha di Indonesia yang memiliki eksistensi penting namun kadang-kadang dianggap terlupakan dalam percaturan kebijakan adalah Usaha Kecil dan Menengah (UKM). Padahal jika mengenal lebih jauh dan dalam, peran UKM bukanlah sekedar pendukung dalam kontribusi ekonomi nasional (Setyobudi, 2007). Data BPS menunjukkan bahwa UKM dalam perekonomian nasional memiliki peran yang penting dan strategis. Kondisi tersebut dapat dilihat dari berbagai data empiris yang mendukung bahwa eksistensi usaha tersebut cukup dominan dalam perekonomian Indonesia, yaitu: (1) jumlah industri yang besar dan terdapat dalam setiap sektor ekonomi, (2) potensinya yang besar dalam penyerapan tenaga kerja. Setiap unit investasi pada sektor UMKM dapat 
menciptakan lebih banyak kesempatan kerja bila dibandingkan dengan investasi yang sama pada usaha besar (UB).

Usaha Kecil dan Menengah (UKM) sebagai salah satu komponen dalam industri nasional, mempunyai peranan yang sangat penting dalam perekonomian nasional, penyerapan tenaga kerja, pemerataan distribusi hasil-hasil pembangunan, dan penanggulangan kemiskinan. Oleh karena itu, pemerintah telah memiliki pilar-pilar kebijakan strategis yang diimplementasikan melalui berbagai kebijakan/program dan kegiatan tahunan untuk mendukung pengembangan dan penguatan UKM di Indonesia. Usaha Mikro dan Kecil (UKM) umumnya memiliki keunggulan dalam bidang yang memanfaatkan sumberdaya alam dan padat karya, misalnya pertanian tanaman pangan, perkebunan, peternakan, perikanan, perdagangan dan restoran.

Disisi lain, perekonomian Indonesia masih didominasi oleh sektor dengan produktivitas yang rendah, yaitu: sektor pertanian, perdagangan dan industri rumah tangga. Pada sektor dengan produktivitas yang rendah inilah jumlah usaha mikro dan kecil, dan menengah (UMKM) terkonsentrasi (Munizu, 2010). Berbagai permasalahanpermasalahan selalu terdapat pada kebanyakan UKM. Hal tersebut dapat menghambat UKM untuk dapat berkembang dengan baik, terutama dalam mengoptimalkan peluang yang ada. Kondisi tersebut memberikan isyarat bahwa UKM sepantasnya diberikan bantuan dan pengembangan sesuai dengan kebutuhannya (Sulaeman, 2004).

Menurut Hafsah (2004) pengembangan UKM perlu mendapatkan perhatian yang besar baik dari pemerintah maupun masyarakat agar dapat berkembang lebih kompetitif bersama pelaku ekonomi lainnya. Kebijakan pemerintah kedepan perlu diupayakan lebih kondusif bagi tumbuh dan berkembangnya UKM. Pemerintah perlu meningkatkan perannya dalam memberdayakan UKM di samping mengembangkan kemitraan usaha yang saling menguntungkan antara pengusaha besar dengan pengusaha kecil, dan meningkatkan kualitas sumber daya manusianya.

Secara umum pertumbuhan ekonomi kota Medan tidak terlepas dari kontribusi UKM. Hal ini dapat dilihat dari jumlah UKM-nya cukup banyak dengan jumlah lebih kurang 2.42.890 UMKM yang terdiri dari jenis perdagangan jasa, industri kerajinan, dan aneka usaha lainnya. Berdasarkan data Badan Pusat Statistik, proporsi jumlah pengusaha mikro, kecil dan menengah mencapai 99,8 \% dari total usaha ekonomi yang ada di kota Medan. Artinya jumlah UKM mencapai hampir 500 kali lipat dari jumlah usaha besar. Meski demikian, kontribusi UKM ke kota Medan diperkirakan baru mencapai 39,8 \% sedangkan usaha besar mencapai $60,20 \%$. Hal ini menunjukkan kuatnya sektor usaha besar dan masih terbatasnya sektor UKM (BPS Sumatera Utara, 2014).

UKM merupakan salah satu jenis usaha yang mempunyai keunggulan tersendiri salah satunya dalam hal ini pemilik merangkap sebagai manajer perusahaan yang bekerja sendiri dan memiliki gaya manajemen sendiri (merangkap semua fungsi manajerial seperti perencanaan, pengorganisasian pengawasan, penilaian). Pemilik UKM juga dalam pengelolaannya mungkin tidak memiliki kemampuan manajerial yang handal tetapi mungkin hanya berdasarkan pengalaman saja. Namun dalam menjalankan suatu usaha kecil pasti kita berkeinginan untuk mendapatkan keuntungan yang maksimal (profit), melalui pencapaian kinerja atau keberhasilan mencapai tujuan dan hasil yang dapat dirasakan oleh para pedagang kaki lima. Kinerja dalam menjalankan fungsinya tidak berdiri sendiri, tetapi hubungannya dengan kepuasan kerja dan tingkat imbalan, dipengaruhi oleh keterampilan, kemampuan dan sifat-sifat individu. Oleh karena itu, menurut model partner - lawyer (Donnely, Gibson and Ivancevich : 1994), kinerja individu pada dasarnya dipengaruhi oleh faktor-faktor (a) harapan mengenai imbalan, (b) dorongan, (c) kemampuan, kebutuhan dan sifat, (d) persepsi terhadap tugas, (e) imbalan internal dan eksternal, (f) persepsi terhadap tingkat imbalan dan kepuasan kerja. Dengan demikian pada dasarnya ditentukan oleh tiga hal, yaitu : (1) lingkungan, (2) kemampuan, dan (3) keinginan (Ardiana, 2010).

Berdasarkan latar belakang di atas perlu dilakukan penelitian tentang pengaruh motivasi dan kemampuan managerial terhadap kinerja UKM di Kota Medan .

\section{Rumusan Masalah}

Bagaimaa pengaruh motivasi dan kemampuan manajerial terhadap kinerja usaha kecil dan menengah di kota Medan.

\section{Tujuan Penelitian}

Untuk mengetahui pengaruh motivasi dan kemampuan manajerial terhadap kinerja usaha kecil dan menengah di kota Medan.

\section{Metode Penelitian}

Penelitian dilakukan terhadap para pelaku UKM di wilayah Kecamatan Medan Selayang, Medan Sunggal, Medan Johor dan Medan Baru. Data Peneltian ini diperoleh dari penyebaran kuesioner sebanyak 80 responden kepada pelaku UKM di Kota Medan. Variabel operasional dalam penelitian ini terdiri dari 2 (dua) variabel independen (X) yaitu motivasi dan kemampuan managerial, serta 1 (satu) variabel dependen (Y) yaitu kinerja usaha.

Teknik analisis yang digunakan adalah analisis regresi linier berganda.Penulis menggunakan alat analisis ini untuk mengetahui hubungan linier yang terjadi antara variabel independen dengan variabel dependen. Analisis regresi linier berganda dilakukan dengan bantuan program SPSS. 


\section{B. LANDASAN TEORI}

\section{Motivasi}

Motivasi (motivation) diartikan sebagai kekuatan, dorongan, kebutuhan, semangat, tekanan, atau mekanisme psikologi yang mendorong seseorang atau sekelompok orang untuk mencapai prestasi tertentu sesuai dengan apa yang dikehendakinya. Dalam arti kognitif, motivasi diasumsikan sebagai aktivitas individu untuk menentukan kerangka dasar tujuan dan penentuan perilaku untuk mencapai tujuan.itu. Dalam arti afeksi, motivasi bermakna sikap dan nilai dasar yang dianut oleh seseorang atau sekelompok orang untuk bertindak atau tidak bertindak (Sudarman, 2004 : 2).

Gibson, dkk (2009: 94) menjelaskan bahwa "motivasi diartikan sebagai konsep yang menguraikan tentang kekuatan-kekuatan yang ada dalam diri karyawan yang memulai dan mengarahkan perilaku". Siagian (2011 : 102) menjelaskan bahwa "motivasi merupakan daya dorong bagi seseorang untuk memberikan kontribusi yang sebesar mungkin demi keberhasilan organisasi dalam mencapai tujuannya". Dengan pengertian bahwa tercapainya tujuan organisasi berarti tercapai pula tujuan pribadi para anggota organisasi yang bersangkutan.

Dari pendapat di atas didefenisikan bahwa motivasi adalah proses yang menghasilkan suatu intensitas, arah dan ketekunan individual dalam kelompok untuk mencapai suatu tujuan. Unsur intensitas, arah dan ketekunan tersebut menyangkut seberapa kerasnya seseorang berusaha dalam mendapatkan sesuatu. Unsur inilah yang paling dominan dalam motivasi. Kemudian karyawan yang termotivasi sangat mengerti tujuan dan tindakan mereka dan meyakini juga tujuan tersebut akan tercapai. Inilah bentuk motivasi yang paling efektif.

Berdasarkan pengertian-pengertian tersebut, dapat disimpulkan bahwa manfaat motivasi itu sendiri adalah meningkatkan gairah kerja karyawan, menumbuhkan disiplin yang tinggi, meningkatkan kreatifitas dan partisipatif setiap karyawan sehingga tercipta produktivitas karyawan yang tinggi.

\section{Kemapuan Manajerial}

Dewasa ini persaingan dan perkembangan dunia usaha semakin kuat dan tajam sehingga untuk meningkatkan usaha diperlukan penanganan yang serius dari setiap pengusaha untuk dapat bersaing dengan perusahaan lain. Dimana untuk meningkatkan keberhasilan usaha salah satu upaya yang harus dilakukan yaitu dengan meningkatkan sumber daya internal. Sumberdaya internal yang paling penting adalah kemampuan managerial.

Menurut Yuyun Wirasasmita (Suryana, 2011 : 10), "bahwa faktor internal yang paling penting dalam mempengaruhi keberhasilan usaha adalah kewirausahaan dan managerial". Keberhasilan usaha atau dunia bisnis sangat tergantung pada kemampuan managerial dan kewirausahaan, pemimpin perusahaan tersebut memanfaatkan peluang dan mengelola semua sumber secara optimal dan produktif. Sebab itu kemampuan managerial dan kewirausahaan mutlak dikembangkan melalui pendidikan, latihan, lokakarya dan kesempatan-kesempatan memperoleh wawasan yang lebih luas.

Kemampuan manajerial adalah kemampuan untuk mengelola usaha seperti perencanaan, pengorganisasian, pemberian motivasi, pengawasan dan penialaian (Siagian, 2011). Adapun fungsi manajemen yang digunakan para pelaku UKM, sebagai berikut: (a)Perencanaan, (b) Pengambilan keputusan, (c) Penganggaran, (d) Pengorganisasian, (e) Pengkoordinasian dan (f) Pengawasan.

Jika seseorang pengusaha telah memiliki kemampuan managerial maka pengusaha itu telah meyakini perencanaan, pengorganisasian, penggerakan dan pengawasan, ditunjang dengan kreativitas, keinovasian, dan berani mengambil resiko. Dengan sendirinya tujuan yang hendak dicapai akan terpenuhi.

Kemampuan managerial adalah kemampuan untuk menggerakkan orang lain dalam memanfaatkan sumber-sumber yang ada dalam mencapai tujuan organisasi secara efisien dan efektif. Ukuran seberapa efisien dan efektifnya seorang manager adalah seberapa baik dia menetapkan rencana dalam mencapai tujuan yang memadai, kemampuan memimpin secara efektif merupakan kunci keberhasilan organisasi.

Berdasarkan pendapat para ahli dan hasil penelitian dapat disimpulkan bahwa kemampuan manajerial berpengaruh dalam menentukan keberhasilan usaha. Sehingga para pengusaha dalam meningkatkan usahanya dituntut untuk meningkatkan kemampuan managerial

\section{Kinerja Usaha}

Kinerja, adalah hasil kerja yang dapat dicapai oleh seseorang atau kelompok orang dalam organisasi dan merupakan sarana penentu dalam suatu proses untuk mencapai tujuan organisasi. Kinerja organisasi harus dapat diukur berdasarkan ukuran tertentu dan dalam kesatuan waktu. Indikator kinerja meliputi : keuntungan, kondisi keuangan, hasil produk mampu bersaing, jumlah pelanggan yang dimiliki, jumlah penjualan, kepuasan karyawan akan kompensasi dan motivasi karyawan (Ardiana, dkk., 2010).

Kinerja dalam menjalankan fungsinya tidak berdiri sendiri, tapi berhubungan dengan kepuasan kerja dan tingkat imbalan, dipengaruhi oleh keterampilan, kemampuan dan sifat-sifat individu. Oleh karena itu, menurut model partner-lawyer, kinerja individu pada dasarnya dipengaruhi oleh faktor-faktor; (a) harapan mengenai imbalan; (b) dorongan; (c) kemampuan; kebutuhan dan sifat; (d) persepsi terhadap tugas; (e) imbalan internal dan eksternal; (f) persepsi terhadap tingkat imbalan dan kepuasan kerja. Dengan demikian, kinerja pada dasarnya ditentukan oleh tiga hal, yaitu: (1) kemampuan, (2) keinginan dan (3) lingkungan. Oleh karena itu, agar mempunyai kinerja yang baik, seseorang harus mempunyai keinginan yang tinggi untuk mengerjakan serta mengetahui pekerjaannya. 
Tanpa mengetahui ketiga faktor ini kinerja yang baik tidak akan tercapai. Dengan kata lain, kinerja individu dapat ditingkatkan apabila ada kesesuaian antara pekerjaan dan kemampuan. Kinerja individu dipengaruhi oleh kepuasan kerja. Kepuasan kerja itu sendiri adalah perasaan individu terhadap pekerjaannya. Perasaan ini berupa suatu hasil penilaian mengenai seberapa jauh pekerjaannya secara keseluruhan mampu memuaskan kebutuhannya (Ardiana, dkk., 2010).

Kinerja adalah hasil yang diperoleh oleh suatu organisasi baik organisasi tersebut bersifat profit oriented atau non oriented yang dihasilkan selama satu periode waktu. Secara lebih tegas Armstrong dan Baron mengatakan kinerja merupakan hasil pekerjaan yang mempunyai hubungan kuat dengan tujuan strategis organisasi, kepuasan konsumen, dan memberikan kontribusi ekonomi (Armstrong dan Baron, 2008)

Ardiana (2010) mengungkapkan, bahwa kinerja individu pada dasarnya dipengaruhi oleh faktor-faktor : (1) Harapan mengenai imbalan; (2) Dorongan; (3) Kemampuan, kebutuhan dan sifat; (4) Persepsi terhadap tugas; (5) Imbalan internal dan eksternal; dan (6) Persepsi terhadap tingkat imbalan dan kepuasan kerja.Dengan demikian, kinerja pada dasarnya ditentukan oleh tiga hal, yaitu: (1) kemampuan, (2) keinginan dan (3) lingkungan.

\section{PEMBAHASAN}

\section{Analisa}

Pengujian regresi linear berganda menjelaskan besarnya motivasi dan kemampuan managerial terhadap kinerja usaha kecil dan menengah. Hasil analisis regresi dengan perhitungan yang menggunakan software SPSS selengkapnya dapat dilihat pada uraian berikut.

Berdasarkan hasil tersebut maka persamaan regresi linier berganda yang mempunyai formulasi :

$$
\mathrm{Y}=\mathrm{b}_{0}+\mathrm{b}_{1} \mathrm{X}_{1}+\mathrm{b}_{2} \mathrm{X}_{2}+\varepsilon
$$

Sehingga diperoleh persamaan:

$$
\mathrm{Y}=-1,444+0,272 \mathrm{X}_{1}+0,318 \mathrm{X}_{2}
$$

Dengan estimasi simpangan baku peramalan sebesar 1,210

Deskripsi dari persamaan regresi linear berganda di atas adalah sebagai berikut :

$\mathrm{b}_{0}:-1,444$

Bilangan konstanta $\left(b_{0}\right)$ sebesar $-1,444$ menunjukkan besarnya kinerja usaha apabila motivasi dan kemampuan managerial sama dengan 0 .

$\mathrm{b}_{1}: 0,272$

Koefisien regresi pertama $\left(b_{1}\right)$ sebesar 0,272 menunjukkan besarnya pengaruh motivasi terhadap kinerja UKM dengan asumsi kemampuan managerial konstan. Artinya apabila faktor motivasi meningkat 1 satuan nilai, maka diprediksi kinerja UKM meningkat sebesar 0,272 satuan nilai dengan asumsi kemampuan managerial konstan.

$\mathrm{b}_{2}: 0,318$

Koefisien regresi kedua $\left(b_{2}\right)$ sebesar 0,318 menunjukkan besarnya pengaruh kemampuan managerial terhadap kinerja UKM dengan asumsi motivasi konstan. Artinya apabila faktor kemampuan managerial meningkat 1 satuan nilai, maka diprediksi kinerja UKM meningkat sebesar 0,318 satuan nilai dengan asumsi motivasi konstan.

\section{a. Uji Simultan (uji F)}

Uji ini bertujuan untuk menguji signfikannya pengaruh pengetahuan dan kemampuan managerial secara simultan terhadap kinerja UKM seperti pada Tabel 1.

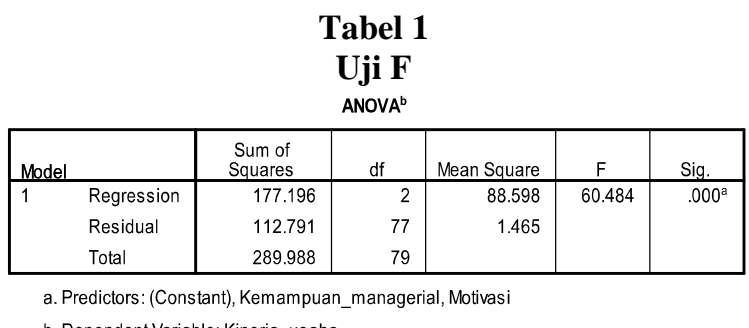

b. Dependent Variable: Kinerja_usah

Prosedur dan kriteria penerimaan serta penolakan hipotesis ditetapkan sebagai berikut :

a. Hipotesis :

$\mathrm{H}_{0}$ : Tidak ada pengaruh motivasi dan kemampuan managerial yang signifikan terhadap kinerja UKM.

$\mathrm{H}_{1}$ : Ada pengaruh motivasi dan kemampuan managerial yang signifikan terhadap kinerja UKM.

b. Alfa $(\alpha)=0,05 ; \mathrm{k}$ (jumlah variabel yang dianalisis $=3$ ); $\mathrm{N}=80$, maka berdasarkan F-tabel didapatkan nilai F-tabel $5 \%(2: 79)$ sebesar 3,11.

c. Kriteria penerimaan dan penolakan hipotesis Jika $\mathrm{F}_{\text {hitung }}>\mathrm{F}_{\text {tabel }}$ maka $\mathrm{H}_{0}$ ditolak atau $\mathrm{H}_{1}$ diterima, sedangkan apabila $\mathrm{F}_{\text {hitung }}<\mathrm{F}_{\text {tabel }}$ maka $\mathrm{H}_{0}$ diterima atau $\mathrm{H}_{1}$ (hipotesis yang diajukan) ditolak.

d. Berdasarkan uji $\mathrm{F}$ diketahui $\mathrm{F}_{\text {hitung }}$ sebesar $60,4849>\mathrm{F}_{\text {tabel }} 3,11$, sehingga $\mathrm{H}_{0}$ ditolak atau $\mathrm{H}_{1}$ diterima. Hal ini menunjukkan bahwa morivasi dan kemampuan managerial secara simultan berpengaruh signifikan terhadap kinerja UKM.

\section{b. Uji Parsial (uji t)}

Untuk mengetahui pengaruh parsial dari setiap variabel motivasi dan kemampuan managerial terhadap kinerja UKM Kuliner dilakukan dengan uji $\mathrm{t}$ seperti pada Tabel 2 .

Tabel 2

Uji t

Pengaruh Motivasi dan Kemampuan Managerial terhadap Kinerja UKM 


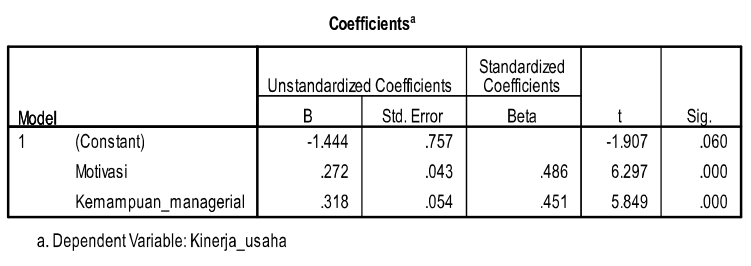

1). Uji hipotesis pengaruh motivasi terhadap kinerja $\operatorname{UKM}\left(\mathrm{X}_{1}\right)$.

Prosedur dan kriteria penerimaan serta penolakan hipotesis ditetapkan sebagai berikut :

a. Hipotesis

$\mathrm{H}_{0}: \quad \mathrm{b}_{1}=0$ artinya, motivasi tidak mempunyai pengaruh terhadap kinerja UKM.

$\mathrm{H}_{1}: \mathrm{b}_{1} \neq 0$ artinya, motivasi mempunyai pengaruh positif terhadap kinerja UKM.

b. Uji Hipotesis

Bila $\mathrm{t}_{\text {hitung }}>\mathrm{t}_{\text {tabel }}(\alpha, \mathrm{N}-\mathrm{k}-1)$, maka $\mathrm{H}_{0}$ ditolak artinya motivasi mempunyai pengaruh secara signifikan terhadap kinerja UKM dan apabila $\mathrm{t}_{\text {hitung }}<\mathrm{t}_{\text {tabel }}$, maka $\mathrm{H}_{0}$ diterima, artinya motivasi tidak mempunyai pengaruh secara signifikan terhadap kinerja UKM.

c. Berdasarkan hasil pengolahan dengan program SPSS diketahui $t_{\text {hitung }}$ sebesar 6,297.

d. Dengan $\alpha=5 \%, t_{\text {tabel }}(5 \% ; 78)$ diperoleh nilai $t_{\text {tabel }}$ sebesar 1,646. Dari uraian tersebut dapat diketahui bahwa $t_{\text {hitung }}(6,297)>t_{\text {tabel }}$ $(1,646)$, maka dapat disimpulkan $\mathrm{H}_{1}$ diterima, artinya motivasi berpengaruh secara signifikan terhadap kinerja UKM.

2). Uji hipotesis pengaruh kemampuan managerial terhadap kinerja UKM $\left(\mathrm{X}_{2}\right)$

Prosedur dan kriteria penerimaan serta penolakan hipotesis ditetapkan sebagai berikut :

a. Hipotesis

$\mathrm{H}_{0}: \mathrm{b}_{1}=0$ artinya, kemampuan managerial tidak mempunyai pengaruh terhadap kinerja UKM.

$\mathrm{H}_{1}: \mathrm{b}_{1} \neq 0$ artinya, kemampuan managerial mempunyai pengaruh positif terhadap kinerja UKM.

b. Uji Hipotesis

Bila $t_{\text {hitung }}>t_{\text {tabel }}(\alpha, N-k-1)$, maka $\mathrm{H}_{0}$ ditolak artinya kemampuan managerial mempunyai pengaruh secara signifikan terhadap kinerja UKM dan apabila $t_{\text {hitung }}<t_{\text {tabel }}$, maka $\mathrm{H}_{0}$ diterima, artinya kemampuan managerial tidak mempunyai pengaruh secara signifikan terhadap kinerja UKM.

c. Berdasarkan hasil pengolahan dengan program SPSS diketahui $t_{\text {hitung }}$ sebesar 5,849.

d. Dengan $\alpha=5 \%, t_{\text {tabel }}(5 \% ; 80)$ diperoleh nilai $t_{\text {tabel }}$ sebesar 1,646. Dari uraian tersebut dapat diketahui bahwa $t_{\text {hitung }}(5,849)>t_{\text {tabel }}$ $(1,646)$, maka dapat disimpulkan $\mathrm{H}_{1}$ diterima, artinya kemampuan managerial berpengaruh secara signifikan terhadap kinerja UKM.

Berdasarkan hasil penelitian di atas maka dapat diketahui bahwa motivasi dan kemampuan managerial mempunyai pengaruh signifikan terhadap kinerja UKM, dimana faktor motivasi mempunyai pengaruh yang lebih dominan terhadap kinerja UKM, dibandingkan dengan kemampuan managerial.

\section{Evaluasi}

Hasil penelitian menunjukkan bahwa motivasi dan kemampuan managerial berpengaruh signifikan terhadap kinerja UKM. Motivasi adalah suatu keahlian dalam mengarahkan seorang wirausaha agar mau bekerja secara berhasil, sehingga keinginan dan tujuannya tercapai. Menurut Handoko (2003) bahwa motivasi merupakan salah satu yang dapat mempengaruhi hasil kerja. Seseorang yang memiliki motivasi yang tinggi akan memperoleh hasil yang lebih baik dalam menjalankan usahatanya dibandingkan motivasi yang rendah

Motivasi mempunyai kekuatan kecenderungan seseorang/individu untuk melibatkan diri dalam kegiatan yang mengarah kepada sasaran dalam pekerjaan sebagia kepuasan, tetapi lebih lanjut merupakan perasaan senang atau rela bekerja untuk mencapai tujuan pekerjaan. Motivasi adalah suatu keadaan dalam diri seseorang yang mengaktifkan atau menggerakkan orang tersebut. Hal ini dapat diartikan bahwa dengan motivasi, maka seseorang tergerak atau terdorong untuk berbuat sesuatu. Motivasi dipandang sebagai motor yang menimbulkan energi dalam diri seseorang dan dengan energi tersebut seseorang dapat berbuat sesuatu. Dengan demikian motivasi kerja berpengaruh terhadap penampilan seseorang (performance) sebagai sikap yang positif akan memberikan dampak pada kinerja.

Seorang wirausaha orang yang memiliki ciri inisiatif, memiliki tanggungjawab atau wewenang dan berpandangan ke depan untuk menjangkau kesuksesan usaha. Kapasitas manajemen berkaitan dengan kemampuan seseorang dalam menjalankan fungsi-fungsi manajemen seperti perencanaan, pembuatan anggaran, pelaksanaan dan pengendalian kegiatan-kegiatan perusahaan. Kegiatan manajemen lebih bersifat formal, ilmiah dan karejanya bersifat lebih umum. Manajemen lebih berupa alat dan teknik berdasarkan pertimbangan dan ujicoba rasional yang ditujukan untuk cara-cara penyelesaikan masalah yang benar-benar serupa pada berbagai situasi bisnis.

Kapasitas manajemen yang penuh sangat didukung oleh aspek perencanaan, implementasi dan pengendalian akan sangat ditentukan oleh latar biografi seseorang. Kemampuan kecakapannya dalam berbisnis dan keinginan dan memotivasi yang kuat. Faktor-faktor tersebut sangat banyak ditentukan oleh lingkungan fisik dan lingkungan kelembagaan dimana seseorang tersebut tinggal dan dibesarkan. Faktor-faktor inilah yang membentuk kewirausahaan seseorang. Dengan kata lain, kewirausahaan yang dimiliki seseorang mempengaruhi seseorang dalam mengambil keputusan bisnisnya. 


\section{KESIMPULAN DAN SARAN}

\section{Kesimpulan}

a. Secara simultan motivasi dan kemampuan managerial berpengaruh signifikan terhadap kinerja UKM.

b. Secara parsial menunjukkan bahwa motivasi dan kemampuan managerial memiliki pengaruh secara signifikan terhadap kinerja UKM. Faktor motivasi mempunyai pengaruh yang lebih dominan terhadap kinerja UKM dibandingkan dengan kemampuan managerial.

\section{Saran}

a. Dalam rangka meningkatkan kinerja UKM, disarankan pemilik UKM meningkatkan motivasi dan kemampuan managerial dalam mengelola UKM-nya.

b. 2. Perlu peran pemerintah dalam meningkatkan kemampuan mangerial pengelolaan UKM dengan memberikan pelatihan UKM.

\section{E. DAFTAR PUSTAKA}

Ardiana, 2010. Kompetensi SDM UKM dan Pengaruhnya Terhadap Kinerja UKM di Surabaya. Jurnal Manajemen dan Kewirausahaan, Vol. 12, No. 1, Maret 2010 : $42-55$.
Armstrong, M dan Baron A. 2008. Performance Manajement : The New Realities. Institute of Personnel and Development, New York.

Gibson, James L., John M,dan Donely James H Jr. 2009. Organizational: Behavior, Structur, Processes. New York: The McGraw Hill Companies, Inc.

Munizu, Musran, 2010, Pengaruh Faktor-Faktor Eksternal dan Internal Terhadap Kinerja Usaha Mikro dan Kecil (UMK) di Sulawesi Selatan, Jurnal Manajemen dan Kewirausahaan 12, 33-41.

Setyobudi, Andang, 2007, Peran Serta Bank Indonesia dalam Pengembangan Usaha Mikro, Kecil dan Menengah (UMKM), Buletin Hukum Perbankan dan Kebanksentralan 5, 29-35.

Siagian, Sondang P. 2011. Manajemen Sumber Daya Manusia. Bumi Aksara, Jakarta.

Sudarman D. 2004. Motivasi, Kepemimpinan, dan Efektifitas Kelompok. PT. Rineka Cipta, Jakarta.

Sulaeman, Suhendar, 2004, Pengembangan Usaha Kecil dan Menengah dalam Menghadapi Pasar Regional dan Global, Infokop 25, 113120.

Suryana, Sumantri. 2011. Perilaku Organisasi. Universitas Padjajaran, Bandung.. 